\title{
QUALITY ASSESSMENT OF HYBRID MAIZE SEEDS ACCORDING TO THEIR SHAPE AND SIZE
}

\section{PROCENA KVALITETA HIBRIDNOG SEMENA KUKURUZA PREMA OBLIKU I VELIČINI SEMENA}

\author{
Marijenka TABAKOVIĆ ${ }^{*}$, Violeta ORO**, Rade STANISAVLJEVIĆ**, Ratibor ŠTRBANOVIĆ**, Mile SEČANSKI* \\ *Maize Research Institute, ZemunPolje, Slobodana Bajića 1, 11185 Belgrade-Zemun, Serbia \\ ${ }^{* *}$ Institute for Plant Protection and Environment, Teodora Drajzera 9, 11040 Belgrade, Serbia \\ e-mail:mtabakovic@mrizp.rs
}

\begin{abstract}
Maize seed is characterised by a variety of shapes and sizes, which directly or indirectly affect physiological properties. The aim of the present study was to establish the significance of the seed shape and size on the first count and germination. The following eight hybrids were used as a seed material in the trial: ZP196, ZP260, ZP341, ZP360, ZP434, ZP677, ZP684 and ZP704. The traits of seed shape and size were observed under laboratory conditions. The seed mass, the first count and germination were determined. The genotype and the seed fraction significantly affected the variance of seed mass formation, $R 2 \geq 0,911$, while the significance of these factors for the first count and germination was small with the coefficient of determination of $\mathrm{R} 2 \leq 0.129$ and $\leq 0.298$, respectively. The first count and germination were high (above 95\%) in all sizes and all shapes of seeds. The lowest first count and germination were detected in SO (94.2; 95.1, respectively), while the highest values were determined in SSP (97.1; 98.0, respectively). The importance of seed germination was determined by the analysis of variance $(\mathrm{p}<0.05)$.
\end{abstract}

Keywords: seed, physical properties, uniformity

\section{REZIME}

Seme kukuruza odlikuje se raznovrsošću oblika i veličina, koje po srednoilineposrednoutičuna fiziološke osobine. Ciljrada je bio da se utvrdi značaj oblika i veličine semenana energiju I klijavost semena. U ogledu kao semenski material korišćeno je osam hibrida (ZP196, ZP260, ZP341, ZP360, ZP434, ZP 677, ZP684, ZP704. U laboratorijskim uslovima posmatrane su osobine oblika i veličine seme. Izvojeno je četiri frakcija SP. SO. SSP, SSO. Od osobina određena je masa semena, energija klijanja, klijavost. Genotip i frakcija semena imale su značajnog uticaja na varijansu formiranja mase semena $R^{2} \geq 0,911$, dok za energiju i klijavost značaj ovih faktora je mali sa koeficijentom determinacije $R^{2} \leq 0,129$ odnosno $R^{2} \leq 0,298$. Struktura semena na klipu podeljena u frakcije ukazuje na veće prisustvo sinih frakcija u odnosu na srednje sitne, a po obliku ujenačenije su pljosnate frakcije, izmeđukojih ne postoji statistička značajnost. Energija klijanja i klijavost semena kod svih veličina i oblika semena je visoka iznad 95\%. Najmanja energija i klijavost je za seme SO $(94,2 ; 95,1)$, a najveća za seme SSP $(97,1 ; 98,0)$.Istraživanja su pokazala da podele semena po frakcijama ima značaja radi ujednačavanja semenskog materijala i jedan je od osnovnih uslova za dobru semensku i merkantilnu proizvodnju. Naročito je značajno u prvim fazama razvitka klijanaca, što kasnije ima uticaja na prinos useva.

Ključne reči: seme, fizičke osobine, ujednačenost

\section{INTRODUCTION}

The amount and utility value of the produced maize seed classify this cereal into one of the economically most important crops. It is an important source of carbohydrates, proteins, iron, vitamin $\mathrm{B}$, and minerals and accounts for about $15 \%$ of the energy intake of the population (Badu-Apraku et al., 2011; Ngo Nonga et al., 2008). Seed maize growing practices have to follow the constant increase in demand for this raw material. Although maize yield increased, there was a significant seasonal yield variation due to the variation of weather factors (Ray et al., 2015; Sun et al., 2016; Farmaha et al., 2016. The constant openended research question in the use of maize hybrid seed in the crop commercial production is how and on what bases to uniformity the properties of seeds originating from various combinations and produced under different agroecological conditions in order to more fully and accurately use the effects of heterosis contained in a hybrid combination, i.e. genotypic constitution of the hybrid maize seed.

The main goal of any production, whether commercial or seed one, is to obtain high-quality seed for further use. Physical properties (seed shape and size) depend on agroecological conditions during seed formation and maturation. Moreover, physiological properties (the first count and germination) also depend on these conditions. Concerning scientific-research and technological-research aspects, germination is a morphological and physiological trait of hybrid maize seed, which depends on the traits of the germ and the seed, but also on environmental conditions under which it is tested or expressed. Seeds can be considered a key element in crop success. This property, along with other properties of seed quality, is a determining factor for germination and the establishment of crops in a fast and uniform way, in diverse environmental conditions (Rajjou et al., 2012; Marcos Filho et all, 2015; Finch-Savage and Basselet all, 2015; Wen et al., 2018).

The aim of the study was to determine the significance of the seed shape and size in achieving good physiological traits of seeds.

\section{MATERIAL AND METHOD}

Seeds of eight maize hybrids developed at the Maize Research Institute, Zemun Polje (ZP196, ZP260, ZP341, ZP360, ZP434, ZP677, ZP684, ZP704) were used as a seed material on which the study was performed.

Physical (shape, size and mass) and physiological traits (first count and germination) were the objectives of the study. 
Samples of 25 ears were drawn after harvest and were dried and processed using a Carter Day laboratory modular precision sizer. The following shapes and sizes were obtained: round (O) and flat (P) and small (S) and medium-small seeds (SS), resulting in four seed fractions: SO, SP, SSO and SSP.

A 1000-seed mass was determined with the standard laboratory method prescribed in the ISTA Rules 2019: by measuring $10 \times 100$ seeds.

The fist count and total germination were determined with a standard method set up in the ISTA Rules:

$-\mathrm{T}=20 / 30^{\circ} \mathrm{C}$ (alternately seven days $16 / 8 \mathrm{~h}$, white light up to 1200 lux at $30^{\circ} \mathrm{C}$, air humidity up to $60 \%$ ).

Obtained experimental data were processed by the appropriated mathematical and statistical methods using the IBM SPSS 19.0 statistical package (version free of charge).

Descriptive statistics were used to process obtained parameters at the annual level. The differences among analysed maize hybrids, as well as their interactions, were established by the analysis of variance (ANOVA) and LSD test.

\section{RESULTS AND DISCUSSION}

The significance of the hybrid combination and the fractions on the expression of physical (shape, mass) and physiological traits (first count and germination) was confirmed by the parametric tests $(\mathrm{p}<0.01, \mathrm{p}<0.05)$. The participation of factors in the formation of the trait 1000 -seed mass was over $90 \%, \mathrm{R}^{2}>$ 0.900 , while the effect of the factors the genotype and the seed fraction was small on physiological traits $\left(\mathrm{R}^{2} \leq 0.095\right.$ for the first count, and $\mathrm{R}^{2} \leq 0.271$ for germination) (Table 1 ). In addition to the direct impact of factors, the significance of their interactions is statistically significant at the level of $p \leq 0.01$

High yields of seed crops are achieved by the selection of genotypes with the highest possible yielding capacity, but also by the selection of high-quality seeds.

The percentage of a certain fraction is a property of each genotype but is also affected by environmental conditions. SO and SP were the least present fractions in all hybrids. The percentage of small fraction in comparison to the medium-small fraction is lower than $25 \%$. The highest percentage was determined for the SSO fraction in four hybrids (ZP341 - 63.47 \%, ZP360, ZP434 and ZP684, >25 \%), (Figure 1, a). The smallest seed mass was detected in SO (222.9g in ZP196), while the highest mass was determined in SSO (414.2 $\mathrm{g}$ in ZP677).
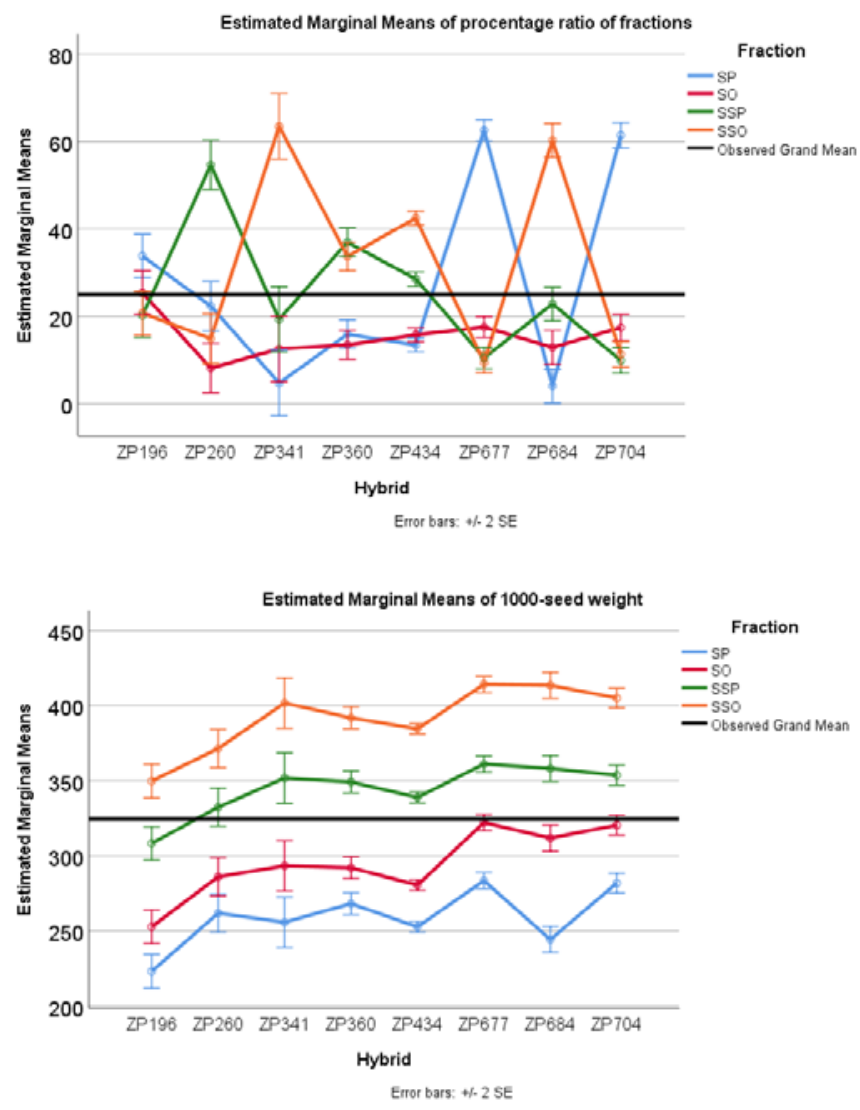

Fig. 1. Content of seed fractions and the 1000-seed mass for hybrid combinations over seed fractions

The values of physiological traits of seeds are high for all

Table 1.Tests of Between-Factors Effects (ANOVA)

\begin{tabular}{|c|c|c|c|c|c|c||}
\hline Source & Dependent Variable & $\begin{array}{c}\text { Type III Sum of } \\
\text { Squares }\end{array}$ & df & $\begin{array}{c}\text { Mean } \\
\text { Square }\end{array}$ & F & Sig. \\
\hline Hybrid & & & & & & \\
\hline & ${ }^{\mathrm{a}} 1000$-seed mass & 199342.426 & 7 & 28477.49 & 101.097 & 0.000 \\
\hline & ${ }^{\mathrm{b}}$ First=count (\%) & 345.845 & 7 & 49.406 & 2.668 & 0.010 \\
\hline Fraction & ${ }^{\mathrm{c}}$ Germination (\%) & 357.909 & 7 & 51.13 & 9.301 & 0.000 \\
\hline & & 13589.57 & 3 & 4529.857 & 80.505 & 0.000 \\
\hline & ${ }^{\mathrm{a}} 1000$-seed mass & 927534.843 & 3 & 309178.3 & 1097.608 & 0.000 \\
\hline & ${ }^{\mathrm{b}}$ First count (\%) & 424.123 & 3 & 141.374 & 7.634 & 0.000 \\
\hline & ${ }^{\mathrm{c}}$ Germination (\%) & 400.008 & 3 & 133.336 & 24.254 & 0.000 \\
\hline & $\mathbf{H y b r i d \times F r a c t i o n ~}$ & 195068,374 & 21 & 9288,97 & 165.084 & 0.000 \\
\hline & ${ }^{\mathrm{a}} 1000$-seed mass & 27675.843 & 21 & 1317.897 & 4.679 & 0.000 \\
\hline Error & ${ }^{\mathrm{b}}$ First=count (\%) & 745.602 & 21 & 35.505 & 1.917 & 0.008 \\
\hline & ${ }^{\mathrm{c}}$ Germination (\%) & 450.261 & 21 & 21.441 & 3.9 & 0.000 \\
\hline & & 45633.338 & 811 & 56.268 & & \\
\hline
\end{tabular}

a R Squared $=.911$ (Adjusted $\mathrm{R}$ Squared $=\mathbf{0 . 9 0 7})$

b R Squared $=.129($ Adjusted $R$ Squared $=0.095$

c R Squared $=.298($ Adjusted $R$ Squared $=0.271)$ 
hybrids and range above $90 \%$. The first count in all hybrids was at the level of the estimated grand mean ( $>95 \%)$ with a larger deviation (89.5 \%) of the SO seed fraction in the hybrid ZP260 (Figure 2, a). Seed germination in relation to the fraction is uniform in all hybrids. The largest variation (sd 2.83) was recorded for SP in the hybrid ZP684. When seeds are processed by their physical traits, they are made uniform by their shape and size, which provides a higher amount of high-quality seed material to be used in sowing (Đokić, 2020). At sowing, the size to germination ratio is particularly important under conditions of drought and high temperatures. For sowing seeds deeper than $4 \mathrm{~cm}$, El-Abady et al. (2015) recommend seeds of the medium round or the large round fraction. These results are in conformity with Shirin et al. (2008), who reported that the seed size had been one of the most important properties of a seed that affected the emergence and seedling vigour. Enayatgholizadeh et al. (2011) reported that larger seedlings were produced from larger seed.
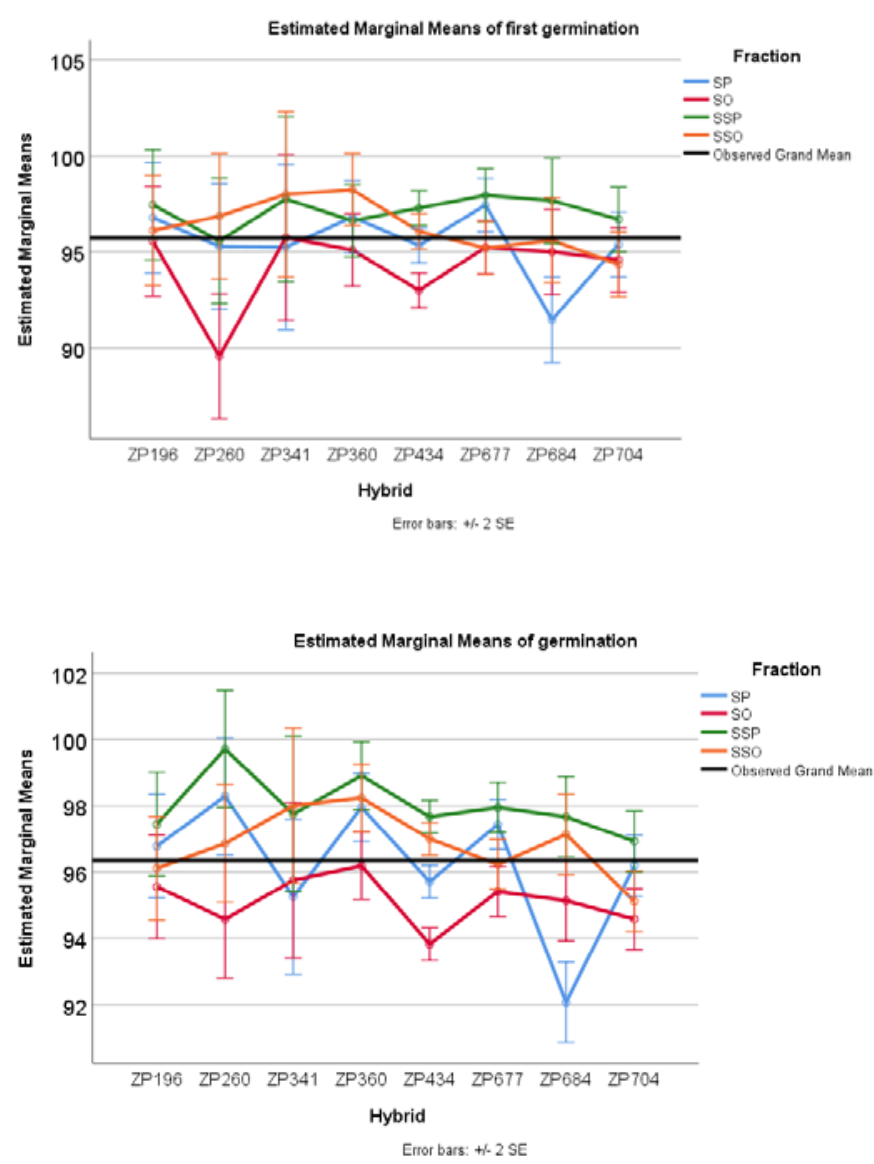

Fig. 2. Mean values of the first count and germination for hybrid combinations over seed fractions

According to obtained and presented mean values of the seed shape and mass, as well as of physical traits, first count and germination, it is observable that there are differences at levels of both, fractions and hybrids. The significance of differences for all traits was determined by the comparative tests of mean values (LSD). The percentage of seeds of a certain size significantly varied over seed fractions (SO, SP, SSP and SSO). There were no differences among flat fractions, whether the seeds were small or medium-sized. Differences in the mass of seeds of various sizes and shapes were significant for all variants (Table 2). The seed size is genetically controlled, but it is also controlled by environmental factors that affect the growth of maize hybrid (Enayat Gholizadeh, 2012). In dependence on the genetic factors, biochemical and physiological abilities of the plant, as well as on temperature, moisture and the presence of available nitrogen in the soil, the duration and the degree of grain filling differ, which results in various seed sizes (Sadras and Egli, 2008).

The first count of the SO fraction was significantly lower than the remaining fractions, as opposed to the SSO fraction that did not differ in the first count from the remaining seed fractions. All differences in germination were significant except the difference between SSO and SP. Based on the individual comparisons of means among seeds of various sizes and shapes, it can be concluded that there were significant differences in the first count and germination among fractions $\mathrm{p} \leq 0.05$ (Table 2 ).

Table 2. Pairwise comparisons(LSD test)

\begin{tabular}{|c|c|c|c|c|c|}
\hline \multicolumn{2}{|c|}{$\begin{array}{c}\text { Pairwise } \\
\text { Comparisons }\end{array}$} & \multicolumn{2}{|c|}{ Mean Difference (I-J) } & \multirow[b]{2}{*}{$\mathrm{FC}$} & \multirow[b]{2}{*}{$\mathrm{G}$} \\
\hline (I) & $(\mathrm{J})$ & Ratio & $\mathrm{AM}$ & & \\
\hline \multirow[t]{3}{*}{$\mathrm{SP}$} & SO & $11.891^{*}$ & $-36.044^{*}$ & $1.246^{*}$ & $1.082 *$ \\
\hline & SSP & 1.922 & $-85.345^{*}$ & $-1.653^{*}$ & $-1.794 *$ \\
\hline & SSO & $-4.759 *$ & $-132.693 *$ & -0.835 & -0.627 \\
\hline \multirow[t]{3}{*}{$\mathrm{SO}$} & SP & $-11.891^{*}$ & $36.044 *$ & $-1.246^{*}$ & $-1.082 *$ \\
\hline & SSP & $-9.969 *$ & $-49.300 *$ & $-2.899 *$ & $-2.876^{*}$ \\
\hline & $\mathrm{SSO}$ & $-16.650 *$ & $-96.649 *$ & $-2.081 *$ & $-1.709 *$ \\
\hline \multirow[t]{3}{*}{ SSP } & SP & -1.922 & $85.345 *$ & \begin{tabular}{|l|}
$1.653 *$ \\
\end{tabular} & $1.794 *$ \\
\hline & $\mathrm{SO}$ & 9.969* & $49.300 *$ & 2.899* & $2.876^{*}$ \\
\hline & $\mathrm{SSO}$ & $-6.681 *$ & $-47.349 *$ & 0.818 & $1.167 *$ \\
\hline \multirow[t]{3}{*}{ SSO } & SP & 4.759* & $132.693 *$ & 0.835 & 0.627 \\
\hline & $\mathrm{SO}$ & $16.650 *$ & $96.649 *$ & $2.081^{*}$ & $1.709 *$ \\
\hline & SSP & $6.681 *$ & 47.349* & -0.818 & $-1.167 *$ \\
\hline
\end{tabular}

AM-1000-seed mass; FC-first count; G-germination; $L S D *-p \leq 0.05$

This result indicates that the producers of hybrid maize seeds can expect significant variation in seed quality due to changes in the seed structure and size. In addition to the hereditary basis, environmental conditions are the most important factors affecting the seed's shape and size. Variability of agroecological conditions may alter the growth and development of maize (Asare et al., 2011; Baoyuan et al., 2016), especially in the initial stages of germination.

\section{CONCLUSION}

The studies show that the classification of seeds in fractions is important for the uniformity of the seed material and is one of the basic conditions for good seed and commercial production. It is especially important in the early developmental stages of seedlings since it later affects crop yield.

Significant differences occurred due to different seed sizes and shapes. The importance of seed germination was determined by the analysis of variance $(\mathrm{p}<0.05)$.

The selection of high-quality seed material is the main prerequisite for high yields.

\section{REFERENCE}

Asare, D.K., J.O. Frimpong, E.O. Ayeh, and H.M. Amoatey. 2011.Water use efficiencies of maize cultivars grown under rain-fed conditions. Agric. Sci. 2:125-130. DOI:10.4236/as.2011.22018 
Badu-Apraku, B.; Akinwale, R. (2011). Identification of earlymaturing maize inbred lines based on multiple traits under drought and low $\mathrm{N}$ environments for hybrid development and population improvement. Canadian Journal of Plant Science, 91, 931-942. DOI:10.4141/CJPS2010-021

Baoyuan Zhou, Yang Yue, Xuefang Sun, Xinbing Wang, Zhimin Wang, Wei Ma, Ming Zhao.2016.Maize Grain Yield and Dry Matter Production Responses to Variations in Weather Conditions. Agron. J. 108:196-204 (2016) DOI:10.2134/agronj2015.0196

Đokić, D. S., R.; Milenković, J.; Koprivica, R.; Knežević, J.; Vuković, A.; Terzić, D. (2020), The effectiveness of the process of cleaning natural alfalfa seeds (Medicago sativa L.) and red clover (Trifoliumpratense L.). Journal on Processing and Energy in Agriculture, 24 (1), 9-12.

El-Abady, M. (2015). Influence of maize seed size/shape, planted at different depths and temperatures on seed emergence and seedling vigor. Research Journal of Seed Science, 8(1), 1-11.

Enayatgholiyzadeh, M.R.; Alami-Saeid; K.H.,Bakhshandeh; A.M., Dehghan-Shoar,M., Ghaineh, M.H., Sharafizadeh, M. (2011). The response of the morphologic characteristics of SC 704 maize affected by the source and seed size in Khuzestan. Australian Journal of Basic and Applied Science, 5:369-374.

Enayat Gholizadeh, M.R. (2012). Assessment of Seedling GreenPercentage, Seedling Green Rate and Seedling Emergence Indexof Corn S.C704 Source Effect and Seed Size in Khuzestan. Australian Journal of Basic and Applied Science, 6: 490-494.

Farmaha, B.S., Lobell, D.B., Boone, K.E., Cassman, K.G., Yang, H.S., Grassini, P. (2016). Contribution of persistent factors to yield gaps in high-yield irrigated maize. Field Crops Research, 186:124-132. DOI:10.1016/j.fcr.2015.10.020

Finch-Savage, W.E., Bassel, G.W.(2015). Seed vigour and crop establishment: extending performance beyond adaptation. Journal of Experimental Botany, 67 (3), 567-591.

ISTA. 2019. Rules for testing seeds. International Seed Testing Association (ISTA), Zurich, Switzerland.
Marcos Filho, J. (2015). Seed vigor testing: an overview of the past, present and future perspective. Scientia Agricola, 72 (4), 363-374. http://dx.doi.org/10.1590/0103-9016-2015-0007

Ngo Nonga, F. (2008). Durabilitédes ActivitésAgricoles des Exploitations FamilialesAgricolesà Base de Maïs du Grand Sud Cameroun, èmesJournées de Recherchesen Sciences Sociales; INRA SFER CIRAD: Lille, France.

Rajjou, L., Duval, M., Gallardo, K., Catusse, J., Bally, J., Job, C., Job, D. (2012). Seed germination and vigor. Annual Review of Plant Biology, 63 (1), 507-533.

DOI:10.1146/annurev-arplant-042811-105550

Ray, D.K., Gerber, J.S., Macdonald, G.K., West, P.C. (2015). Climate variation explains a third of global crop yield variability. Nature Communication, 6:5989. DOI:10.1038/ncomms6989

Sadras, V.O., Egli, D.B. (2008): Seed size variation in grain crops: Allometric relationships between rate and duration of seed growth. Crop Science, 48: 408-416

Shirin, M., Enayatgholiyzadeh, M.R.,Siadat, E.,Fathi,G. (2008). Comparison of suitable seed vigour of hybrid Zea Maize (CV.SC 704) in the field condition of Ahvaz. Congres of Agronomy and Plant Breeding of Iran, Proceedings of the $10^{\text {th }}$, August 18-20, 2008, Karaj, Iran. 330

Sun, H., Zhang, X.,Wang, E.,Chen, S.,Shao, L., Qin, W. (2016). Assessing the contribution of eather and management to the annual yield variation of summer maize using APSIM in the North China Plain. Field Crops Research, 194:94-102. DOI:10.1016/j.fcr.2016.05.007

Wen, D., Hou, H., Meng, A., Meng, J., Xie, L., Zhang, C. (2018). Rapid evaluation of seed vigour by the absolute content of protein in seed within the same crop. Scientific Report, 8 (1), $1-8$.

Received: 20. 02. 2021.

Accepted: 23. 03. 2021. 